\title{
Gender, politics and body
}

\author{
Kalfa Maria \\ Greece \\ Phd Candidate Political Science AUTH \\ Social Anthropologist \\ Gender Studies MSc \\ Multicultural Education MSc \\ Management and Organization of Educational Units MSc \\ Social Policy in crisis situations MSc (on going)
}

\begin{abstract}
This proposal points out FEMEN's action in combination with politics and the naked body in the public space. The body as part of privacy is being reassigned to another context claiming public space and its recognition. Anger, exaggeration and the naked body make up a desperate attempt to highlight issues that are fundamentally feminine and therefore social. The naked body is at the risk of political and social demands, inviting those around it to pay attention to it and give it meaning under a pure and non-sexist and voyeuristic look. In this context, the boundaries between body and authority are constantly intertwined, as the personal is political and the political rights management are gendered.
\end{abstract}

Keywords: gender, politics, body, public space, power

\section{Introduction}

The action of FEMEN has taken on enormous proportions mainly through the media. However, few are aware of FEMEN's action, motivation and goals. There are many who have questioned the way in which this movement has claimed and protested. The body as part of privacy is being reassigned to another context claiming public space and its recognition. Anger, exaggeration, and the naked body make up a desperate attempt to highlight issues that are fundamentally feminine and therefore social. But what is the one that causes the most, the naked body or those that are mentioned in the protests? Behind any form of exaggeration there is always a person who speaks and does not hear, who expresses but does not hear and who tries to speak but is oppressed. "The boundaries of the biological / anatomical body become the 


\section{5th International Conference on New Findings ON HUMANITIES AND SOCIAL SCIENCES}

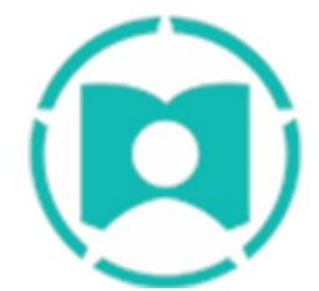

\section{0-22 NOVEMBER, 2020 PARIS, FRANCE}

boundaries of the social" (Athanasiou, 2007). But how does body politics relate to it and why does it combine? The first part presents the approach of the naked body to the action of the Femen the second part presents the representation of the Femen through the media.

Butler formulates the concept of effectiveness, narrative representation, and gender play that is grounded in guidance, imitation, and repetition as in a life-long theatrical performance (Kolliri, 2017: 44). Thus, gender is performed - played in public every time - as a theatrical performance with a specific content and several manifestations. Theatricality runs the action of this movement by presenting a different theme each time, drawing attention to the fine letters, which are often deliberately ignored or ignored by public reason. Theatricality also concerns the way they choose to perform their gender and play with the limits of permissible and not permissible of the moral and non-moral, with the limits that the society has set for them before and without them.

\subsubsection{Purpose and Methodology}

The purpose of this ongoing dissertation is to examine the view of feminist groups and individuals in Greece on the action of Femen and analyze the images and content of these actions. They say that 'an image equals 1000 words'. What could this tell us about the action of Femen, of a naked body in the public space that chooses to provoke and get in the process of playing a (theatrical) role. This team's actions are remarkable as they play with a dip in an unexpected and unexpected way. Public-private dipoles, sexuality-virginity, man-woman, good-bad influence the way their actions are conducted. A woman goes out into public space, claims her sexuality and the reason that this dipole had forbidden her. Thus, the degree of challenge relates to the prejudices and dipoles that the Western world has made and nourished its children.

This movement has received a number of criticisms that focus on the way they present their demands, the way they organize them, as well as their actions on religious issues. Women in the Arab world perceive Femen's message upward from the media as stereotypical, oriental, derogatory, vulgar and largely separate from their everyday reality (Darmoni, Witschge, 2015: 119). Femen not only poses Arab, Muslim women as oppressed by their men, but also poses Arab women (as a homogeneous group) against the "enlightened and liberated" women of the West who are supposed to live in a civilized and superior society . (Darmoni, Witschge, 2015: 125). Whether a religious symbol or religion itself acts aggravatingly or not in the process of women's liberation and gender equality is also a key issue for ... Inna, in the lecture given in Athens in 2018. So religion, with its control over the body, restricts women's movements and establishes a regime that displaces anyone who does not comply with its rationale. The issue of abortion is a burning issue for a woman's rights and how to define her body. Due to the attitude of religion towards abortion and the way in which the woman is constructed as 'Other', they speak of an oppressive power from above in women's bodies and lives. The position of most citizens of mass society ignores the political and ironic part of Femen's performance and focuses 


\section{5th International Conference on New Findings ON HUMANITIES AND SOCIAL SCIENCES}

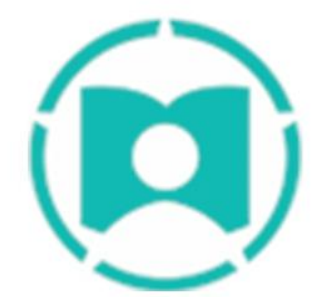

\section{0-22 NOVEMBER, 2020 \\ PARIS, FRANCE}

on the nudity and sexuality of the young female body (Arkhipenko, 2012: 27). In an interview with Le Monde Diplomatique in April 2013, Inna Shevchenko states: "We know what the media needs - sex, scandal and flirting - and we give them that." (Darmoni, Witschge, 2015: 122).

\section{Body and politics: the case of FEMEN}

The naked body is at the risk of political and social demands, inviting those around it to pay attention to it and give it meaning under a pure and non-sexist and voyeuristic look. The naked body, the chest in this case, is seen as a provocation and a sexual fetish that for the wider society cannot be linked to 'serious' political claims and social activism. The 'challenge' lies in the projection of this naked, personal, private part of the female identity, which causes it to be publicized. However, it is not publicized as a sexual fetish, but as a point of harsh and violent negotiation of social and political rights and claims. The naked body of FEMEN is a form of resistance to sexism, religious fundamentalism, homophobia and other social and political issues. Trafficking and 'sexism' make the body abject (Kristeva) by making it unworthy of discourse, a component that FEMEN wishes to label and make it worthy of discourse and attention. The naked body is a taboo subject, and FEMEN 'take advantage' of this to capture their discontent in a graceful and original way.

According to E. Avdela and A. Psarra, 'women' as well as 'men' are historically, socially and culturally constructed. Thus, gender is now becoming a social relationship and a cultural symbol capable of shaping power relations. The FEMEN social movement is a form of social outcry against such things as prostitution, sex trafficking, financial exploitation, psychological, physical and verbal violence. Through this movement it is necessary to highlight the voices of women who have suffered various forms of violence. The 1960s have been significant because not only has there been an increase in new forms of political participation, but also because there have been developments in key conflict stances (Diani \& Della Porta, 2010). After the '60s, new' social movements' emerged with central themes such as women's liberation (Diani \& Della Porta, 2010). According to Melucci, the new social movements themselves challenge existing ideas about politics and society "(Diani \& Della Porta, 2010). As Offe puts it: "movements develop a fundamental post-political critique of social structure and representative democracy, challenging institutional assumptions about conventional ways of 'pursuing politics' in the name of radical democracy (Diani \& Della Porta, 2010). At the same time, Touraine poses a similar problem, who argues that the modern movement does not strive for the conquest of political power, but rather to impart different social content to the general cultural orientations of society (Psimitis: 2006). Notable is the contribution of Melucci, who challenges existing ideas about politics and society, while at the same time emphasizing the body's position in mobilizations, such as the struggle of women (Porta \& Diani: 2010, Neveu: 2010). This theory could form the basis for the meaning that the body attaches to FEMEN's struggles. Melucci also identifies common qualitative elements between feminist movements, sexual liberation movements, and urban movements (Psimitis: 2006). 


\section{5th International Conference on New Findings ON HUMANITIES AND SOCIAL SCIENCES}

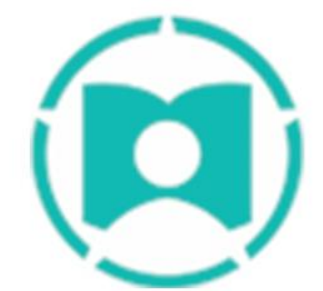

\section{0-22 NOVEMBER, 2020 PARIS, FRANCE}

In Butler's work, gender is a process that is constantly structured and reproduced through a variety of performances, which simultaneously define and limit its actions on the basis of these 'boundaries'. The correctness of an action is defined on the basis of these boundaries, where every culture sets. These boundaries vary from place to place and from year to year, however, in most cases they appear to be restrictive to female identity. Following on from Hegelian dialectic and feminist postmodernist approach and stimulating Beauvoir's position that 'one in not born, but rather becomes a woman', Butler attempts to show that what we call gender, and in particular what we call a feminine, is a social construction (Sakellariou: 2010). The concept of the body consists of a scam: it belongs to nature and to the nonnegotiable, almost sacred character, and belongs to culture, history, language and society (Halkia \& Apostolelli: 2012). The body as part of society is a vehicle of expectations. Expectations concerning women relate to both beauty and youth. The body as a part that represents these two attributes in the Western world is used as a reasoning tool by Femen. According to Cowan, the way the body is used, experienced, and perceived reflects the practical and symbolic structures of the external (physical, social and political) environment (Halkia \& Apostolelli: 2012). The way we choose to dress our body, choose our moves, etc. seems to be limited by the cultural must of each society, with which we grow together, reaching a point of self-preservation. After all, there are many women who criticize other women for not conforming to their cultural norms and their bodies for not adhering to values that define what is right and what is not, what is moral and what is not. A typical example of this thinking is the criticism - even by women - of rape. What the raped woman was wearing, how much of her body she covered, how she sat, how she worked her body throughout the process comes into focus and acts as a marker of her morality. Few clothes = low morality, high level of body exposure = low morality; Society seems to have some rules regarding the body and the code of values of the subjects according to the way they use it. So the body is not just on the sidelines, it is at the center of the shaping of power relations and the culture that sets the boundaries for normality. According to Halkia \& Apostolelli (2012): "ideology or culture is not only in our heads, it is mainly in our bodies.

Many movements have drawn attention to the female body and how it is being violated in public space and under constant surveillance through the Other's gaze. Long before Femen took part in a naked protest, women in Africa used it as a threatening last resort, while making their bodies and personal histories vulnerable as a collective. Igbo and Ibibio women in southeast Nigeria during the women's war of 1929 relied on social scripts around shame to restore their voting rights (Stovall, 2015: 9) Similarly, naked protest has a particular effect when used against perpetrators of domestic violence and gender-based violence. Indian women used naked protest as an overthrow of shame placed on the bodies of the rape victim (Stovall, 2015: 10). 


\section{5th International Conference on New Findings On HUMANITIES AND SOCIAL SCIENCES}

\subsection{FEMEN and Media}

The artistic spectacle of Femen and the very clever use of political parody in conjunction with their exposure to the media make them an unprecedented protest group (Zychowicz, 2011). As Bourdieu points out in Men's Dominion (2007) “... the degree of conformity to [social] roles - in the hierarchical, bipolar repertoire of masculinity and femininity - brings praise or condemnation by making body politics a tool of sustaining authority». We must not forget that the body is not free, natural and innocent, but it is gendered and the result of social expectations and designs, subject to the dictates of the patriarchal dualistic order of things and heteroregularity (Halkia \& Apostolelli: 2012).

"Movements develop new ideas and values by acting as institutions of political change aimed at translating the chronic problems described by community criticism into acute problems, capable of capturing the attention of the media, which is the content of political and social action. (Diani \& Della Porta, 2010: 50) The role of Media is an important component of the emergence of new social movements, perhaps not reflecting objective truth, but promoting new forms of political action and bargaining. However, we do not know whether Femen action can be defined as a series of waves of protest or as an organized social movement. However, the recipients of this television show often both men and women undermine this effort, giving weight not to what has been said but to what has been said. Clearly, these links are also directly related to sexually explicit 'Reasons' about sexuality and political negotiation.

As Ignatio Ramonet points out, media function as centers of truth-building (Psimitis: 2006). According to Psimitis (2006), a blurry picture of social movements within the media is created, a practice that is confirmed in most representations of FEMEN. The truth is that the 'success' of promoting and spreading a movement is largely in the hands of journalists, a practice confirmed by FEMEN. At the same time, Neveu (2010) argues that nationalization and internationalization are important components. These factors have also contributed to the FEMEN study where, although they have visited Greece, their action is based on France and the knowledge of little information on their action, their goals, their repertoire of action and future aspirations. one of which is the 'acquaintance' with Greece and their respective action in this country as well. FEMEN are essentially 'manufactured' and acquire an entity through their promotion by the media. Essentially, the medium becomes the message, as the narratives of the media focus on the naked breasts of women and the abuse of public outrage rather than the message that FEMEN attempts to propagate and promote through this 'weird' way of acting. The recipients of this television show often both men and women undermine this effort, giving weight not to what has been said but to what has been said. Clearly, these links are also directly related to sexually explicit 'Reasons' about sexuality and political negotiation. The tough negotiation of politics has been linked to men's standards and rigorous suits. FEMEN's naked female body is on the sidelines of both political and social reality. Roughly speaking, "... because the structures and institutions of the state and law were created by men to protect their interests, underrepresentation of women is not an unfortunate event easily remedied and we do not fight their patriarchal nature if we simply place more women in political office because political outcomes depend on the power relations of the whole society and not on the individual involved in the decision-making process "(Bryson, 2004: 303). 


\section{5th International Conference on New Findings ON HUMANITIES AND SOCIAL SCIENCES}

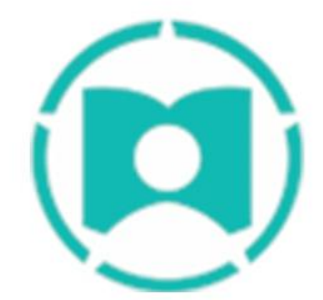

20-22 NOVEMBER, 2020 PARIS, FRANCE

\section{Conclusion}

Femen's controversial topless methods have sparked widespread debate about the diverse notions of feminism both in Ukraine and among global audiences since the group moved abroad in 2012 (Zychowicz, 2015: 79). When we say that the gender body is historical, we mean that it identifies with its gender in continuously modified productions depending on the historical period (Kolliri, 2017: 88). Studying body in the action of Femen is important as it raises issues of politics and gender in an incompatible way - for the most of us-. Politics from the bottom up takes on new dimensions, involving body, politics and gender in an open dialogue in the puplic space.

Mary Douglas, who belongs to the School of Symbolic Anthropology, argues that the body is a model that can mean any kind of system within limits (Gasuka, 2011: 49). In general, the body is approached on the one hand as the tangible framework of the self on the one hand, and on the other as a collective experience (Gasuka, 2011: 50). Some feminist groups criticize the way in which claims of equality and the desire for equality, as presented by them, are negative, for example, a public space for redefining discourses on prostitution, human rights, sex trafficking, religion, femininity, gender, politics, and more. Nude protests have been used in the past and are used to attract the gaze and be heard. Using the body as a tool in the following policy demonstrates how the challenge works to highlight gender issues and not only. However, there are many who accuse this mode of action and are targeted at the bodies themselves rather than the slogans and goals of these actions. At a later stage of the thesis we will highlight the codes around which they act. The slogans written on naked bodies have a lot to say. Perhaps it would be preferable to look at the slogans and meanings they hide or imply. It is also important to depict the approaches of the Greek media to this movement. It is important to note that, according to Femen, there are no Greek women residing here and being members of the movement, although many have expressed their interest. We expect at a later stage to see what Greek feminists support about this movement and how this might be linked or not with the absence of members of Femen in Greece. 


\section{5th International Conference on New Findings ON HUMANITIES AND SOCIAL SCIENCES}

\section{References}

-Athanasiou A. (2007) Life on the Limit: Essays on the Body, Gender and Biopolitics. Athens: Pending

-Apostolelli A. \& Halkia A. (2012) Body, Gender, Sexuality, Athens: Plethron

-Arkhipenko, V. (2012). Reconsidering Private/Public Dichotomy: Examining the Femen Movement through the Arendtian Lens of the Social. Central European University: Voudapest

-Avdella, E. Psarras,. (1997). Silent stories: Women and gender in historical narrative. Athens: Alexandria

-Bourdieu P. (2007) Male domination, Athens: Patakis

-Bryson V. (2004) Feminist Political Theory, Athens: Ephemeral

-Darmoni, K. \& Witschge, T. (2015). Counterpuplics in the age of Mediatisation: Local responses to Femen in nthe arab world In Conjuction: Transdiscinary journal of cultural participation Vol 2(1), p.p. 118-131

-Della Porta D. (2010) Social movements: an introduction. Athens: Review

-Erik Neveu, Sociology of Social Movements and Movement Stories from the Middle Ages to the Present (2010). Marlene Logothetis ed, Athens: Savvala Publications

-Gasuka, M. (2011). Gender Systems, Symbols and the Body In H. Vitsilakis, M. Gassouka, G. Papadopoulos (ed.) Gender and Culture. Athens: Interaction, pp. 41-59

-Zychowicz, J. (2011). Two bad words: Femen and Feminism in Independent Ukraine. In Anthropology of East Europe Review, 29(2), p.p. 215-227

-Zychowicz, J. (2015). Performing Protest: Femen, Nation and the Marketing of Resistance in N. Kravets \& O. Onuch (edit) Journal of Ukrainian Politics and Society, Vol 1(1) p.p.79-104 


\section{5th International Conference on New Findings ON HUMANITIES AND SOCIAL SCIENCES}

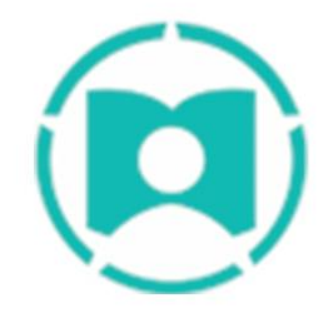

20-22 NOVEMBER, 2020 PARIS, FRANCE

-Kolliri, C. (2017). Gender as Bait: Psychoanalysis, Politics and Art. Athens: Pataki Publications

- M.A., Stovall, (2015). Femen and Muslima Pride: Locating Muslim Women in a German Landscape. University of Colorado

-Psimitis M. (2006) Introduction to modern social movements. Athens: Route

-Sakellariou A. (2010), Book Review of:

Judith Butler (2009), Unrest in Gender: Feminism and Identity Reversal Athens: Alexandria Judith Butler (2009) The Psychic Life of Power, Athens: Plethron

Judith Butler (2009) Accounting for the Self, Athens: Pending 